\title{
SISTEM PENDUKUNG KEPUTUSAN PEMILIHAN PEGAWAI PENERIMA REWARD MENGGUNAKAN PENDEKATAN TOPSIS
}

\author{
Sudaryono ${ }^{1}$, Rochmawati ${ }^{2}$ \\ ${ }^{1}$ Dosen Program Pasca Sarjana Universitas Raharja \\ ${ }^{2}$ Alumni Program Pasca Sarjana Universitas Raharja \\ Jl. Jendral Sudirman No. 40 Modern Cikokol Tangerang Banten 15117 \\ E-mail: sudaryono@ raharja.infom ${ }^{1}, \underline{\text { Rochmawati@Raharja.info }}{ }^{2}$
}

\begin{abstract}
The provision of employee reward for the best performance and achievement of duty is required to do by the organization/institution as the form of recognition and appreciation for the employees and as part of the organizational goal achievement process. This research aimed to develop a decision support system (SPK)) using TOPSIS method with PHP programming language and MySQL database to choose employees receiving rewards in Universitas Serang Raya. The data used derived from 2 groups namely educational employees consisting of lecturers and non-educational ones consisting of official employees. The criteria applied in the educational employees are 10 that are length of employment, dp3 value, percentage value of work attendance, percentage value of the lecturing attendance, value of the lecturer's functional position, value of research deeds, value of community devotion, value of the questionnaire result by students, value of employment status, and value of sanctions. The criteria applied in the non educational employees are 5 that are length of employment, dp3 value, percentage value of work attendance, value of employment status, and value of sanctions. The result of this research is an information system program as a support decision tool for choosing employees receiving rewards.
\end{abstract}

Keywords: TOPSIS method, employees, reward, SPK

\section{Pendahuluan}

Perguruan Tinggi Sebagai penyelenggara pendidikan tinggi memiliki peran strategis meningkatkan daya saing bangsa dalam menghadapi globalisasi disegala bidang. Hal tersebut ditegaskan dalam pasal 58 Undang-Undang Nomor 12 Tahun 2012 tentang pendidikan Tinggi, bahwa fungsi dan peran Perguruan Tinggi adalah sebagai : (1) Wadah pembelajaran mahasiswa dan masyarakat; (2) Wadah Pendidikan calon pemimpin bangsa; (3) Pusat Pengembangan Ilmu Pengetahuan dan Teknologi; (4) Pusat kajian kebajikan dan kekuatan moral untuk mencari dan menemukan kebenaran; dan (5) Pusat pengembangan peradaban bangsa.

Pada masa sekarang ini, sebagian besar universitas telah menurun dalam pengembangan organisasinya disebabkan dari kinerja yang buruk, moral staff yang 
rendah dan pergantian pegawai yang tinggi karena buruknya atau kurangnya program manajemen penghargaan yang efektif (Kirunda, 2010). Menurut Dalvi and Ebrahimi (2013) sistem penghargaan yang dirancang dengan baik menciptakan rasa memiliki diantara pegawai dalam suatu organisasi, itu meningkatkan pertumbuhan dan pengembangan pegawai, dan meningkatkan harga diri pegawai dan ini menjadi pengembangan organisasi yang lebih sehat.

Peranan manajemen sumber daya manusia diakui sangat menentukan bagi terwujudnya tujuan, tetapi untuk memimpin sangatlah sulit dan rumit. Tenaga kerja manusia selain mampu, cakap, dan terampil yang tidak kalah penting juga adalah kemampuan dan kesanggupan mereka untuk bekerja dengan efektif dan efisien. Kemampuan dan kecakapan kurang berarti jika tidak dibarengi dengan moral kerja yang baik yang akan menunjang dalam mewujudkan tujuan. Keberhasilan pencapaian suatu tujuan organisasi tentunya tidak hanya ditentukan oleh besarnya dana yang dimiliki, teknologi yang digunakan ataupun sarana dan prasarana, akan tetapi ada hal yang paling menentukan dalam penyatuan faktor-faktor yang ada dalam perusahaan tersebut yaitu faktor sumber daya manusia. Faktor inilah yang menggerakan seluruh faktor-faktor yang dimiliki organisasi dalam rangka proses pencapaian tujuan.

Faktor pegawai berperan penting dalam melaksanakan proses pencapaian tujuan organisasi, kualitas pegawai baik secara individu maupun sebagai team kerja dalam perusahaan. Berdasarkan Peraturan Kepegawaian Universitas Serang Raya yang dimaksud dengan Pegawai adalah setiap orang yang terikat secara formal atau yang secara administratif terdaftar sebagai pegawai yang diangkat dan diberhentikan oleh Yayasan, yang ditempatkan di Yayasan atau Universitas, dan diserahi tugas baik sebagai tenaga edukatif maupun tenaga non edukatif. Pegawai edukatif yang selanjutnya dalam tesis ini disebut Dosen adalah pegawai yang diberi tugas sebagai tenaga fungsional yang bertanggung- jawab terhadap pelaksanaan Tri Dharma Perguruan Tinggi, yaitu pendidikan dan pengajaran, penelitian, serta pengabdian kepada masyarakat sesuai dengan bidang ilmunya. Pegawai non edukatif yang selanjutnya dalam tesis ini disebut pegawai adalah pegawai yang ditempatkan sebagai tenaga penunjang pelaksanaan kegiatan akademik dan di luar kegiatan akademis. 
Hal ini pula yang terjadi di Universitas Serang Raya pada sistem pemilihan pegawai penerima reward masih dilakukan dengan sistem manual sehingga hal inilah yang menjadi dasar penelitian. Penelitian yang dilakukan adalah membuat sistem pendukung keputusan berupa sistem informasi yang dapat memberikan pertimbangan dalam pengambilan keputusan pemilihan pegawai penerima reward. Metode yang digunakan untuk menangani permasalahan ini, adalah TOPSIS (Technique for Order Performance by Similarity to Ideal Solution). Bahasa pemrograman yang digunakan adalah PHP dan database MySQL.

Kemampuan pengambilan keputusan yang cepat dan cermat menjadi kunci keberhasilan dalam persaingan global dan untuk mengambil sebuah keputusan tentu diperlukan analisis dan perhitungan yang matang, tergantung dengan sedikit banyaknya kriteria yang mempengaruhi permasalahan yang membutuhkan suatu keputusan, oleh karena itu dibutuhkan sistem yang berbasis komputer yang dapat digunakan untuk menentukan pegawai penerima reward.

Tujuan dibuatnya penelitian ini adalah sebagai berikut :

1. Tercapainya objektivitas hasil keputusan sistem pemilihan pegawai dengan kriteria yang digunakan dalam penentuan pegawai penerima reward terdiri dari dua klasifikasi yaitu : dosen berdasarkan kriteria : masa kerja, nilai Daftar Penilaian Pelaksanaan Pekerjaan (DP3), nilai prosentase kehadiran, nilai prosentase kehadiran mengajar, jabatan fungsional, nilai penelitian, nilai pengabdian, nilai kuesioner, status kepegawaian, SP/sanksi dan pegawai berdasarkan kriteria : masa kerja, nilai Daftar Penilaian Pelaksanaan Pekerjaan (DP3), nilai prosentase kehadiran, status kepegawaian, SP/sanksi untuk mendapatkan reward di Universitas Serang Raya.

2. Dapat memberikan alternatife terbaik dalam sistem pengambilan keputusan pemilihan pegawai penerima reward di Universitas Serang Raya dengan menggunakan metode TOPSIS (Technique for Order Performance by Similarity to Ideal Solution).

3. Digunakannya sistem pendukung keputusan sebagai alat untuk memilih pegawai penerima reward sehingga Rektor dapat melakukan pengambilan keputusan berdasarkan rekomendasi sistem yang dibuat. 


\section{TINJAUAN PUSTAKA}

Menurut Luthans (2000) menggarisbawahi dua jenis penghargaan yaitu yang berupa finansial (ekstrinsik) dan yang berupa non-finansial (intrinsik) dan keduanya dapat secara positif mempengaruhi peningkatan kinerja pegawai. Penghargaan finansial artinya pemberian terkait pada kinerja, yang antara lain berupa: bonus, promosi jabatan, komisi, tips, pemberian dan hadiah, dan lain-lain. Penghargaan Non finansial tidaklah berupa uang melainkan berupa pengakuan masyarakat, pujian, dan lain-lain. Penghargaan ini dapat meningkatkan kinerja mereka dan memberikan tanda untuk mereka apakah sudah bertindak baik atau buruk (Sarvadi, 2010)

Thomas (2009) juga menjelaskan bahwa penghargaan ekstrinsik menjadi berkurang nilainya sementara motivasi lebih terdorong/menguat karena disebabkan oleh penghargaan intrinsik. Di saat yang sama, menurut Hasaan Fazal (2011), penghargaan intrinsik sebenarnya memenuhi faktor intrinsik pegawai atau motivasi dan berhasil memotivasi dirinya. Penghargaan sudah dianggap sebagai instrumen penting yang berkaitan dengan kinerja pegawai dan pegawai yang mendapat penghargaan dengan baik merasa dirinya dihargai oleh perusahaan dimana dia bekerja (Sajuyigbe, et al., 2013). Menurut Sinclair (2005), kekuatan memotivasi misalnya berupa pemberian uang terbukti mampu menarik perhatian pegawai dapat memotivasi dan mempertahankannya sehingga mencapai kinerja yang lebih baik.

SDLC memiliki beberapa model dalam penerapan tahapan prosesnya. Salah satunya adalah metode SDLC waterfall (air terjun). Secara umum tahapan pada model waterfall (Menurut Ian Sommerville) requirement definition, system and software design, implementation and unit testing, integration and system testing, operation and maintenance, sesuai gambar berikut ini :

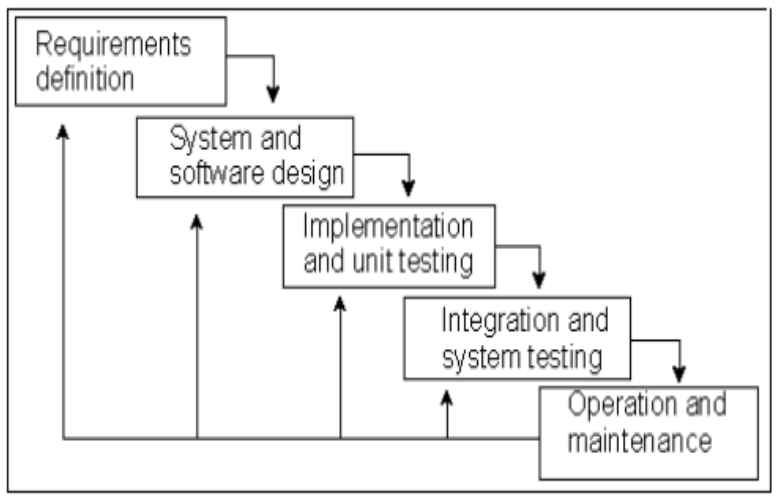

Gambar 1. tahapan pada model waterfall 
TOPSIS adalah salah satu metode pengambilan keputusan multikriteria yang pertama kali diperkenalkan oleh Yoon dan Hwang (1981). TOPSIS bertujuan untuk menentukan solusi ideal positif dan solusi ideal negative. Solusi ideal positif memaksimalkan kriteria manfaat dan minimal kan kriteria biaya, sedangkan solusi ideal negative memaksimalkan kriteria biaya dan meminimalkan kriteria manfaat. Dalam metode TOPSIS, alternatif yang optimal adalah yang paling dekat dengan solusi ideal positif dan paling jauh dari solusi ideal negatif. Velasquez dan Hester (2013) mengamati kelebihan dan kekurangan dari metode TOPSIS, serta wilayah penggunaan aplikasi dengan menggunakan TOPSIS, dalam tabel berikut :

Tabel 1

Kelebihan, kekurangan dan Wilayah Penggunaan Aplikasi dengan metode TOPSIS

\begin{tabular}{|c|c|c|}
\hline Kelebihan & Kekurangan & Wilayah Penggunaan aplikasi \\
\hline $\begin{array}{l}\text { Memiliki proses } \\
\text { yang sederhana, } \\
\text { mudah digunakan } \\
\text { dan diprogram. } \\
\text { jumlah langkah } \\
\text { tetap sama tidak } \\
\text { tergantung dari } \\
\text { jumlah attribute }\end{array}$ & $\begin{array}{l}\text { Penggunaan jarak euclidean } \\
\text { pada TOPSIS tidak } \\
\text { mempertimbangkan } \\
\text { korelasi attribute, sulit } \\
\text { untuk bobt dan menjaga } \\
\text { konsistensi penilaian }\end{array}$ & \begin{tabular}{lcr} 
Manajemen & persediaan & dan \\
logistik, & teknik, & sistem \\
manufaktur, & bisnis & dan \\
pemasaran, & \multicolumn{2}{c}{ lingkungan, } \\
manajemen & sumber daya \\
manusia dan & manajemen sumber \\
daya air &
\end{tabular} \\
\hline
\end{tabular}

Berikut adalah langkah-langkah metode TOPSIS secara lengkap :

1. Mendefinisikan permasalahan yang akan diselesaikan dengan metode TOPSIS.

2. Membuat matriks keputusan sesuai dengan permasalahan yang akan dipecahkan dengan ketentuan sebagai berikut :

$$
D=\left[\begin{array}{ccc}
x 11 & x 12 \ldots & x 1 n \\
x 21 & x 22 \ldots & x 2 n \\
\ldots & \ldots & \ldots \\
x m 1 & x m 2 \ldots & x m n
\end{array}\right]
$$

3. Kemudian lakukan normalisasi matriks dengan persamaan 


$$
r_{i j}=\frac{x_{i j}}{\sqrt{\sum_{i=1}^{m} x_{i j}^{2}}}
$$

Dimana $\mathrm{r}_{\mathrm{ij}}$ merupakan matriks hasil normalisasi dari matriks dasar permasalahannya, dengan $\mathrm{i}=1,2,3, \ldots . \mathrm{m}$, dan $\mathrm{j}=1,2,3 \ldots \mathrm{n}$. Sedangkan $\mathrm{x}_{\mathrm{ij}}$ merupakan matriks dasar yang akan dinormalisasikan. Untuk setiap $i$ menunjukkan baris dari matriks, dan untuk setiap $j$ menunjukkan kolom dari setiap matriks.

4. Lakukan normalisasi matrik $r_{i j}$ menggunakan rating bobot sehingga diperoleh matrik rating bobot ternormalisasi, persamaan yang digunakan adalah sebagai berikut :

$$
\mathrm{y}_{\mathrm{ij}}=\mathrm{w}_{\mathrm{i}} \cdot \mathrm{r}_{\mathrm{ij}}
$$

dimana $\mathrm{y}_{\mathrm{ij}}$ adalah matriks rating terbobot, $\mathrm{w}_{\mathrm{i}}$ adalah bobot rating ke $i$, dan $\mathrm{r}_{\mathrm{ij}}$ adalah matriks hasil normalisasi pada langkah ke dua. Untuk $\mathrm{i}=1,2, \ldots, \mathrm{m}$, dan $\mathrm{j}$ $=1,2, \ldots, \mathrm{n}$. Dalam hal ini, bobot rating harus ditentukan berdasarkan jumlah variabel keputusan yang sedang diselesaikan.

5. Tentukan solusi ideal positif $\left(\mathrm{A}^{+}\right)$dan solusi ideal negatif $\left(\mathrm{A}^{-}\right)$berdasarkan nilai matriks rating terbobot pada langkah ke-3. Berikut persamaan yang digunakan untuk mencari nilai solusi ideal positif dan nilai solusi ideal negative

$$
\begin{aligned}
& A^{+}=\left(y_{1}^{+}, y_{2}^{+}, \ldots, y_{n}^{+}\right) \\
& A^{-}=\left(y_{1}^{-}, y_{2}^{-}, \ldots, y_{n}^{-}\right)
\end{aligned}
$$

Dengan ketentuan :

$$
\begin{aligned}
& y_{i}^{+}=\left\{\begin{array}{l}
\max y_{i j}: \text { Jika } j \text { adalah atribut keuntungan } \\
\min y_{i j}: \text { Jika } j \text { adalah atribut biaya }
\end{array}\right. \\
& y_{i}^{-}=\left\{\begin{array}{l}
\max y_{i j}: \text { Jika } j \text { adalah atribut biaya } \\
\min y_{i j}: \text { Jika } j \text { adalah atribut keuntungan }
\end{array}\right.
\end{aligned}
$$

6. Tentukan jarak antara nilai terbobot setiap alternatif terhadap solusi ideal positif dan solusi ideal negatifnya. Untuk menentukan jarak antara nilai terbobot setiap alternatif terhadap solusi ideal positif, digunakan persamaan sebagai berikut :

$$
D_{i}^{+}=\sqrt{\sum_{i=1}^{n}\left(y_{i}^{+}-y_{i j}\right)^{2}}
$$


Sedang untuk menghitung jarak antara nilai terbobot setiap alternatif terhadap solusi ideal negatif, digunakan persamaan berikut :

$$
D_{i}^{-}=\sqrt{\sum_{i=1}^{n}\left(y_{i j}-y_{i}^{-}\right)^{2}}
$$

7. Langkah terakhir adalah menghitung nilai preferensi untuk setiap alternatif dengan persamaan :

$$
V_{i}=\frac{D_{i}^{-}}{D_{i}^{-}+D_{i}^{+}}
$$

Metode TOPSIS banyak digunakan untuk menyelesaikan pengambilan keputusan secara praktis. Hal ini disebabkan konsepnya sederhana dan mudah dipahami, komputasinya efisien, dan memiliki kemampuan mengukur kinerja relatif dari alternatif-alternatif keputusan.

\section{METODOLOGI PENELITIAN}

\section{Perhitungan Perhitungan Metode TOPSIS untuk Dosen}
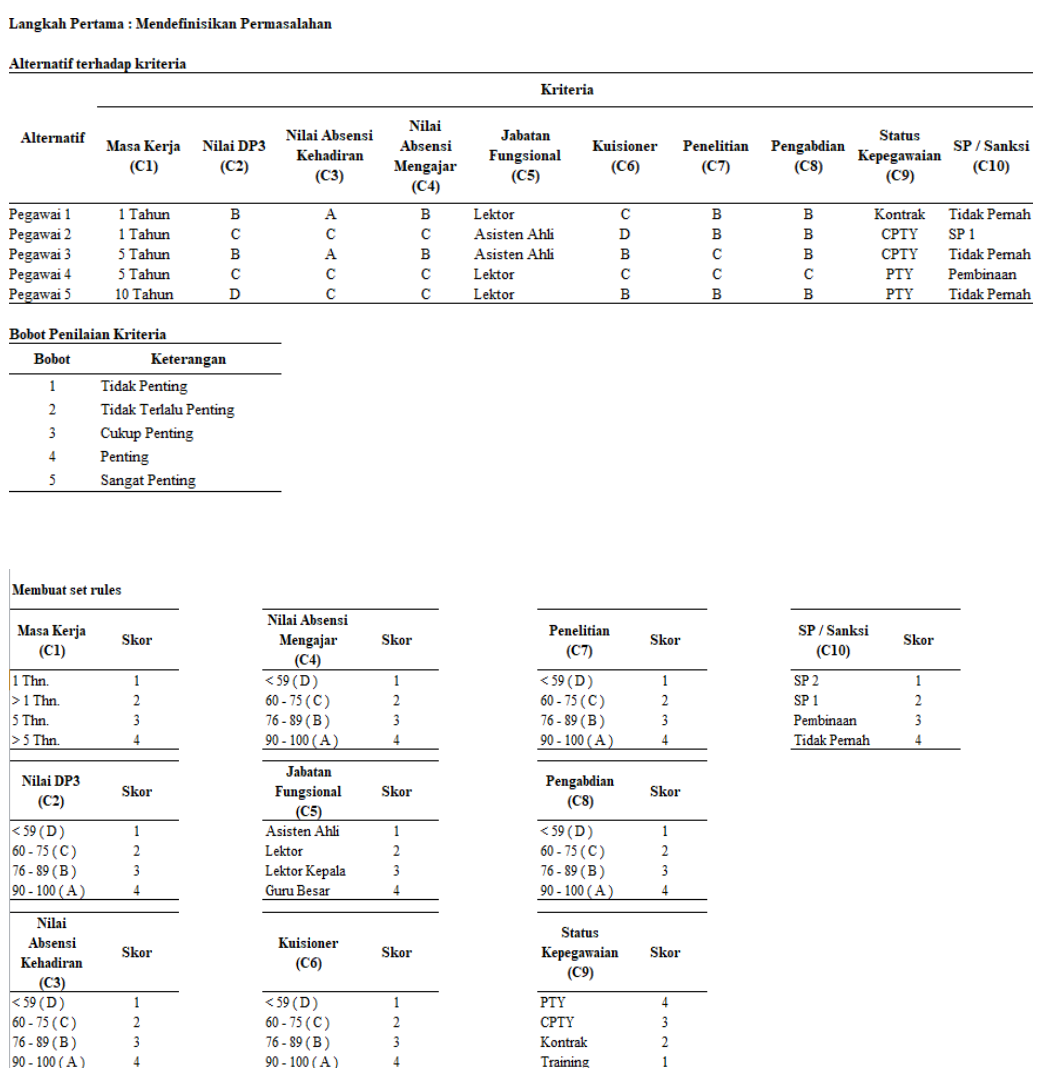


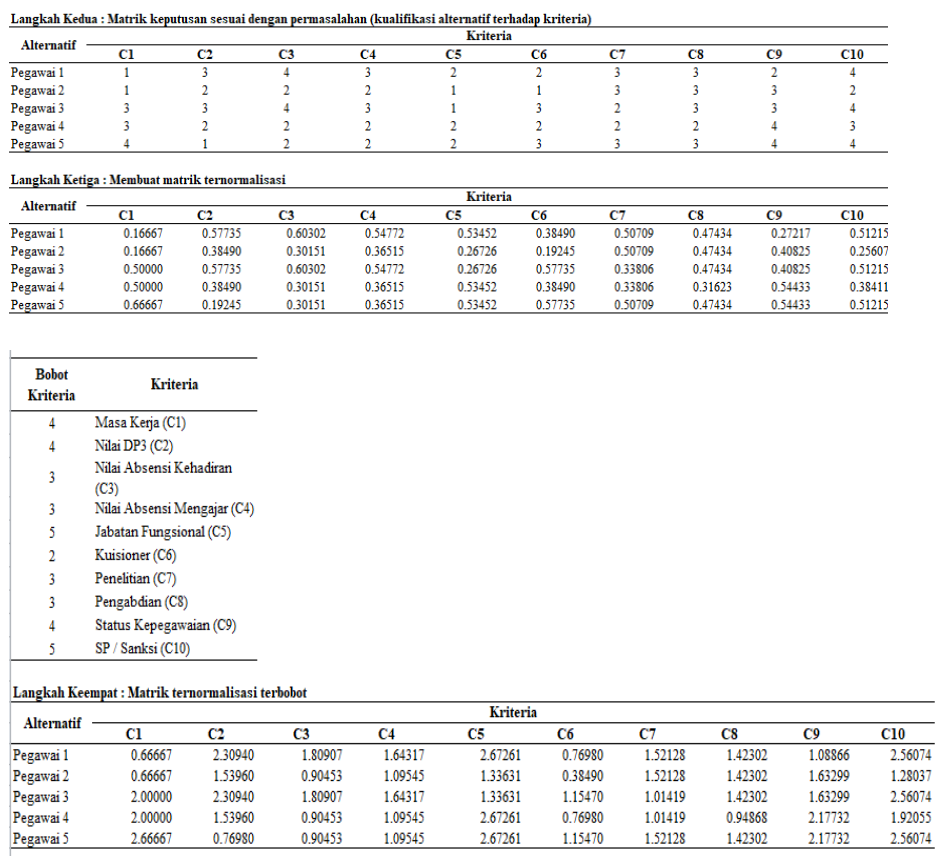

\begin{tabular}{lc}
\multicolumn{2}{c}{ Langkah Kelima : Menentukan Solusi ideal positif dan solusi ideal negatif } \\
\hline $\begin{array}{c}\text { Solusi ideal } \\
\text { positif }\end{array}$ & $\begin{array}{c}\text { Nilai ideal } \\
\text { positif }\end{array}$ \\
\hline Y1+ & 2.66667 \\
Y2+ & 2.30940 \\
Y3+ & 1.80907 \\
Y4+ & 1.64317 \\
Y5+ & 2.67261 \\
Y6+ & 1.15470 \\
Y7+ & 1.52128 \\
Y8+ & 1.42302 \\
Y9+ & 2.17732 \\
Y10+ & 2.56074 \\
\hline & \\
\hline Solusi ideal & Nilai ideal \\
negatif & negatif \\
\hline Y1- & 0.66667 \\
y2- & 0.76980 \\
y3- & 0.90453 \\
y4- & 1.09545 \\
y5- & 1.33631 \\
y6- & 0.38490 \\
y7- & 1.01419 \\
y8- & 0.94868 \\
y9- & 1.08866 \\
y10- & 1.28037 \\
\hline
\end{tabular}


Jurnal SIMIKA Vol. 3 No. 2 Tahun 2020

Langkah Keenam : Jarak antara nilai terbobot setiap alternatif terhadap solusi ideal positif dan ideal negatif

\begin{tabular}{lr}
\hline $\begin{array}{c}\text { Jarak } \\
\text { Terbobot } \\
\text { Solusi ideal } \\
\text { positif }\end{array}$ & $\begin{array}{c}\text { Nilai Jarak } \\
\text { Terbobot }\end{array}$ \\
\hline D1+ & 2.30940 \\
D2+ & 3.16618 \\
D3+ & 1.66841 \\
D4+ & 1.78755 \\
D5+ & 1.86777 \\
\hline
\end{tabular}

\section{Jarak}

Terbobot Nilai Jarak

Solusi ideal Terbobot

negatif

\begin{tabular}{ll}
\hline D1- & 2.74662 \\
D2- & 1.17091 \\
D3- & 2.83188 \\
D4- & 2.42884 \\
D5- & 3.11207 \\
\hline
\end{tabular}

Langkah Ketujuh : Nilai Preferensi

\begin{tabular}{lrrrl} 
Alternatif & $\begin{array}{c}\text { Nilai } \\
\text { Preverensi }\end{array}$ & Rangking & & Alternatif \\
\hline V1 & 0.54324 & 4 & & Pegawai 1 \\
V2 & 0.26998 & 5 & & Pegawai 2 \\
V3 & 0.62927 & 1 & Pegawai 3 \\
V4 & 0.57605 & 3 & Pegawai 4 \\
V5 & 0.62493 & 2 & Pegawai 5
\end{tabular}

Perhitungan Metode TOPSIS Untuk Pegawai

\begin{tabular}{|c|c|c|c|c|c|}
\hline \multirow[b]{2}{*}{ Alternatif } & \multicolumn{5}{|c|}{ Kriteria } \\
\hline & Masa Kerja (Cl) & Nilai DP3 (C2) & $\begin{array}{c}\text { Nilai Absensi } \\
\text { Kehadiran (C3) }\end{array}$ & $\begin{array}{c}\text { Status } \\
\text { Kepegawaian (C4) }\end{array}$ & SP / Sanksi (C5) \\
\hline Pegawai 1 & 1 Tahun & B & A & Kontrak & Tidak Pernah \\
\hline Pegawai 2 & 1 Tahun & $\mathrm{c}$ & $\mathrm{C}$ & CPTY & SP 1 \\
\hline Pegawai 3 & 5 Tahun & B & A & CPTY & Tidak Pernah \\
\hline Pegawai 4 & 5 Tahun & $\mathrm{c}$ & $\mathrm{C}$ & PTY & Pembinaan \\
\hline Pegawai 5 & 10 Tahun & D & $\mathrm{C}$ & PTY & Tidak Pernah \\
\hline \multicolumn{6}{|c|}{ Bobot Penilaian Kriteria } \\
\hline Bobot & \multicolumn{2}{|c|}{ Keterangan } & & & \\
\hline 1 & \multicolumn{2}{|l|}{ Tidak Penting } & & & \\
\hline 2 & \multicolumn{2}{|c|}{ Tidak Terlalu Penting } & & & \\
\hline 3 & \multicolumn{2}{|l|}{ Cukup Penting } & & & \\
\hline 4 & \multicolumn{2}{|l|}{ Penting } & & & \\
\hline 5 & \multicolumn{2}{|l|}{ Sangat Penting } & & & \\
\hline
\end{tabular}


Membuat set rules

\begin{tabular}{|c|c|}
\hline Masa Kerja (Cl) & Skor \\
\hline $\begin{array}{l}1 \mathrm{Thn} . \\
>1 \mathrm{Thn} . \\
5 \mathrm{Thn} . \\
>5 \mathrm{Thn} .\end{array}$ & $\begin{array}{l}1 \\
2 \\
3 \\
4 \\
\end{array}$ \\
\hline Nilai DP3 (C2) & Skor \\
\hline $\begin{array}{l}<59(\mathrm{D}) \\
60-75(\mathrm{C}) \\
76-89(\mathrm{~B}) \\
90-100(\mathrm{~A}) \\
\end{array}$ & $\begin{array}{l}1 \\
2 \\
3 \\
4 \\
\end{array}$ \\
\hline $\begin{array}{c}\text { Nilai Absensi } \\
\text { Kehadiran (C3) } \\
\end{array}$ & Skor \\
\hline$<59$ (D) & 1 \\
\hline $60-75(C)$ & 2 \\
\hline $76-89$ (B) & 3 \\
\hline $90-100(\mathrm{~A})$ & 4 \\
\hline
\end{tabular}

Langkah Kedua : Matrik keputusan sesuai dengan permasalahan (kualifikasi alternatif terhadap kriteria)

\begin{tabular}{lccccc}
\hline \multirow{2}{*}{ Alternatif } & \multicolumn{5}{c}{ Kriteria } \\
\cline { 2 - 6 } & C1 & C2 & C3 & C4 & C5 \\
\hline Pegawai 1 & 1 & 3 & 4 & 2 & 4 \\
Pegawai 2 & 1 & 2 & 2 & 3 & 2 \\
Pegawai 3 & 3 & 3 & 4 & 3 & 4 \\
Pegawai 4 & 3 & 2 & 2 & 4 & 3 \\
Pegawai 5 & 4 & 1 & 2 & 4 & 4 \\
\hline
\end{tabular}

Langkah Ketiga : Membuat matrik ternormalisasi

\begin{tabular}{lrrrrr}
\hline \multicolumn{1}{c}{ Alternatif } & \multicolumn{6}{c}{ Kriteria } \\
\cline { 2 - 6 } & \multicolumn{1}{c}{ C1 } & C2 & \multicolumn{1}{c}{ C3 } & \multicolumn{1}{c}{ C4 } & \multicolumn{1}{c}{ C5 } \\
\hline Pegawai 1 & 0.16667 & 0.57735 & 0.60302 & 0.27217 & 0.51215 \\
Pegawai 2 & 0.16667 & 0.38490 & 0.30151 & 0.40825 & 0.25607 \\
Pegawai 3 & 0.50000 & 0.57735 & 0.60302 & 0.40825 & 0.51215 \\
Pegawai 4 & 0.50000 & 0.38490 & 0.30151 & 0.54433 & 0.38411 \\
Pegawai 5 & 0.66667 & 0.19245 & 0.30151 & 0.54433 & 0.51215 \\
\hline
\end{tabular}

Bobot Kriteria Kriteria

\begin{tabular}{ll}
\hline 4 & $\mathrm{C} 1$ \\
4 & $\mathrm{C} 2$ \\
3 & $\mathrm{C} 3$ \\
4 & $\mathrm{C} 4$ \\
5 & $\mathrm{C} 5$
\end{tabular}

Langkah Keempat : Matrik ternormalisasi terbobot

\begin{tabular}{lrrrrr}
\hline \multicolumn{1}{c}{ Alternatif } & \multicolumn{7}{c}{ Kriteria } \\
\cline { 2 - 7 } & C1 & C2 & C3 & C4 & C5 \\
\hline Pegawai 1 & 0.66667 & 2.30940 & 1.80907 & 1.08866 & 2.56074 \\
Pegawai 2 & 0.66667 & 1.53960 & 0.90453 & 1.63299 & 1.28037 \\
Pegawai 3 & 2.00000 & 2.30940 & 1.80907 & 1.63299 & 2.56074 \\
Pegawai 4 & 2.00000 & 1.53960 & 0.90453 & 2.17732 & 1.92055 \\
Pegawai 5 & 2.66667 & 0.76980 & 0.90453 & 2.17732 & 2.56074 \\
\hline
\end{tabular}

Langkah Kelima : Menentukan Solusi ideal positif dan solusi ideal negatif

\begin{tabular}{lr}
$\begin{array}{c}\text { Solusi ideal } \\
\text { positif }\end{array}$ & Nilai ideal positif \\
\hline Y1 + & 2.66667 \\
$\mathrm{Y}^{+}+$ & 2.30940 \\
$\mathrm{Y} 3+$ & 1.80907 \\
$\mathrm{Y} 4+$ & 2.17732 \\
$\mathrm{Y} 5+$ & 2.56074 \\
\hline \multicolumn{2}{c}{} \\
\hline Solusi ideal & Nilai ideal negatif \\
\hline negatif & 0.66667 \\
Y1- & 0.76980 \\
y2- & 0.90453 \\
y3- & 1.08866 \\
y4- & 1.28037 \\
y5- &
\end{tabular}

\begin{tabular}{lc}
$\begin{array}{c}\text { Status } \\
\text { Kepegawaian (C4) }\end{array}$ & Skor \\
\hline PTY & 4 \\
CPTY & 3 \\
Kontrak & 2 \\
Training & 1 \\
\hline SP / Sanksi (C5) & Skor \\
\hline SP 2 & 1 \\
SP 1 & 2 \\
Pembinaan & 3 \\
Tidak Pernah & 4 \\
\hline
\end{tabular}

. 0.51215 
Jurnal SIMIKA Vol. 3 No. 2 Tahun 2020

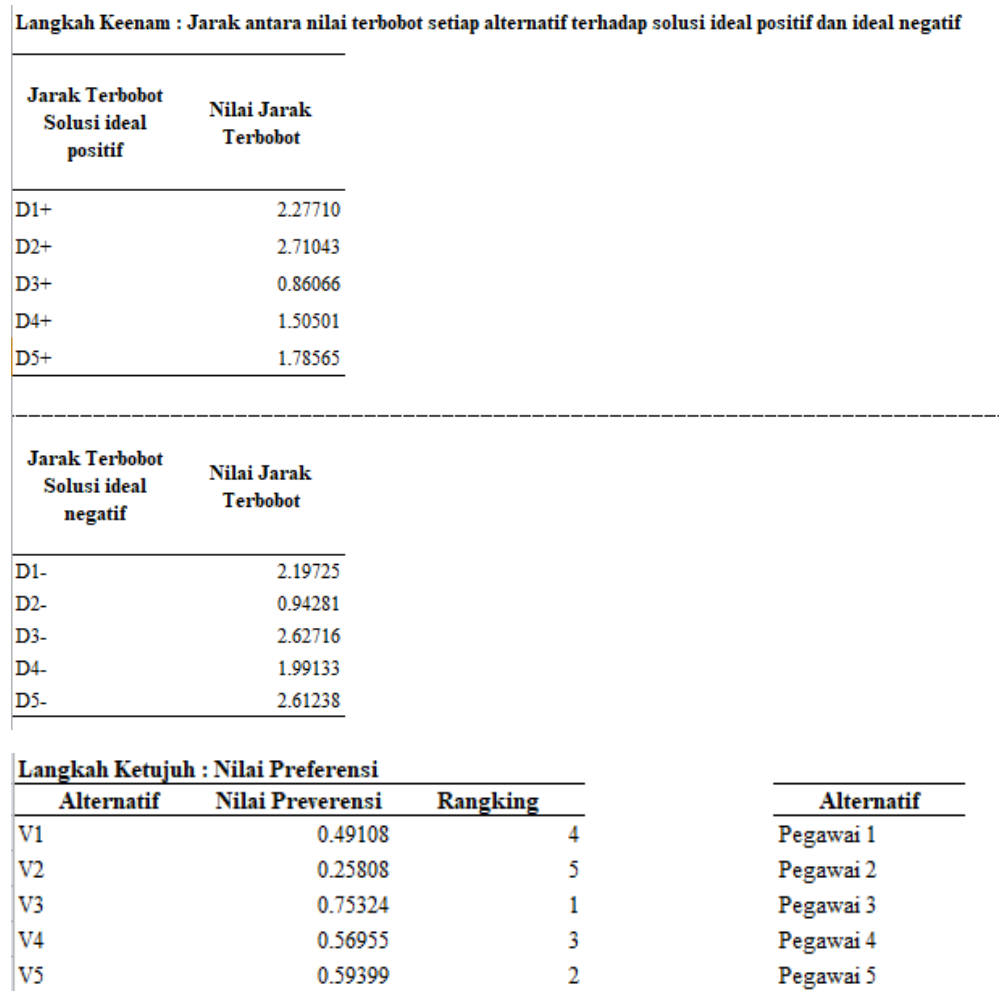

\section{HASIL DAN PEMBAHASAN}

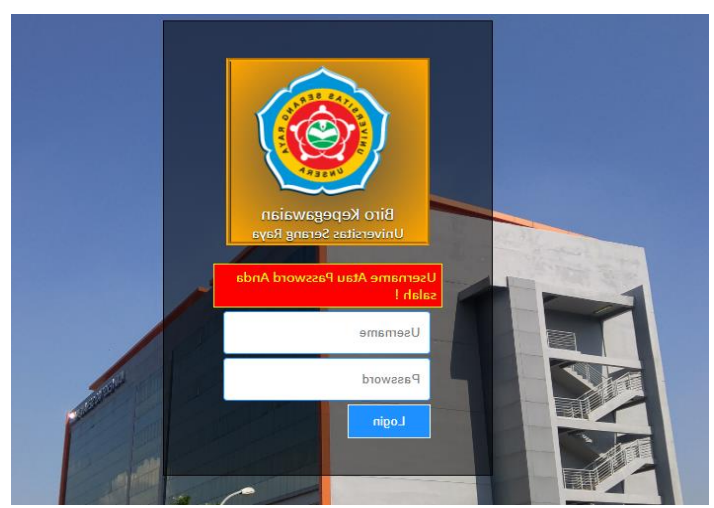

Gambar 2. Form Login

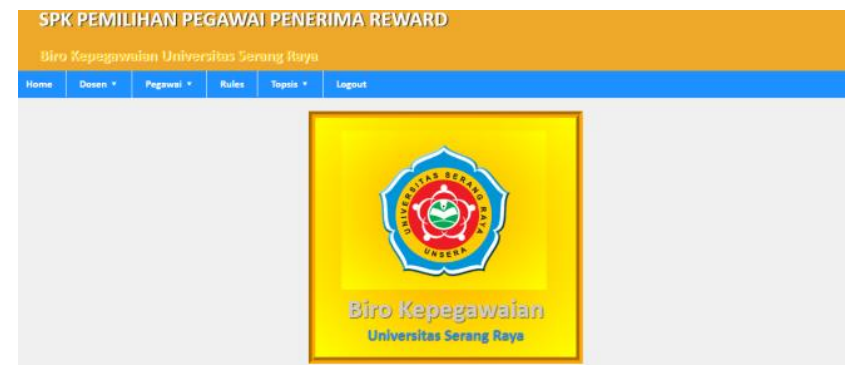

Gambar 3. Form Utama 


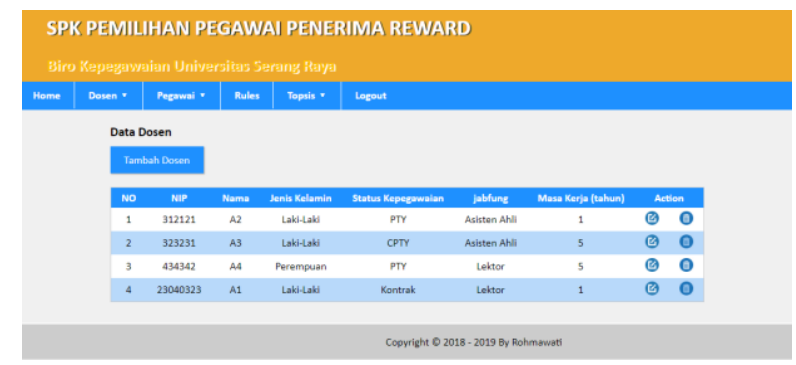

Gambar 4. Kelola Data Dosen

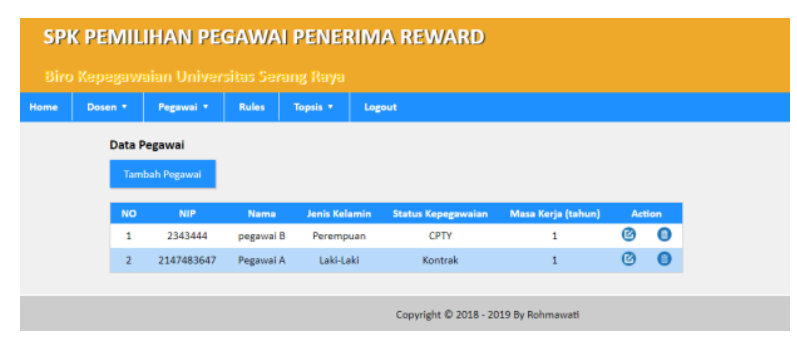

Gambar 5. Kelola Data Pegawai

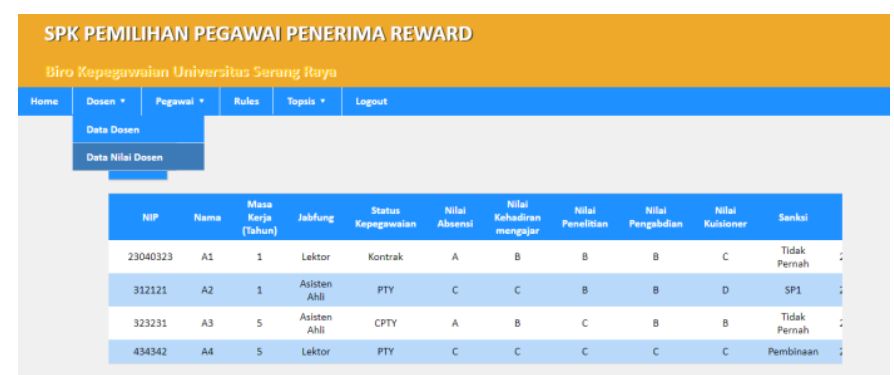

Gambar 6. Kelola Nilai Dosen

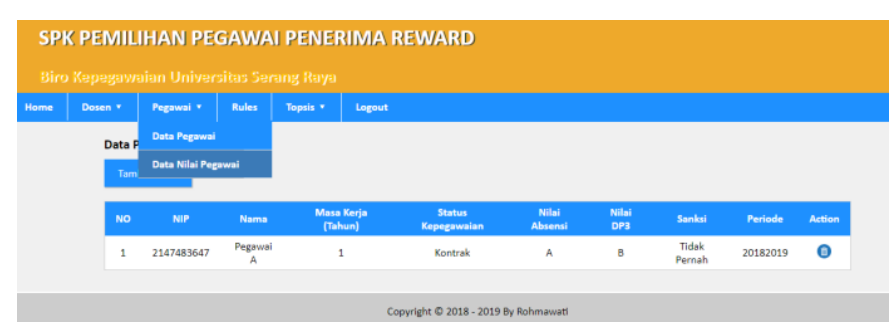

Gambar 7. Kelola Data Nilai Pegawai

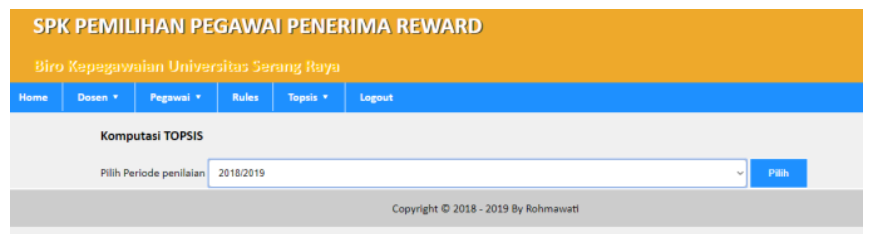

Gambar 8. Periode Tahun Penilaian 


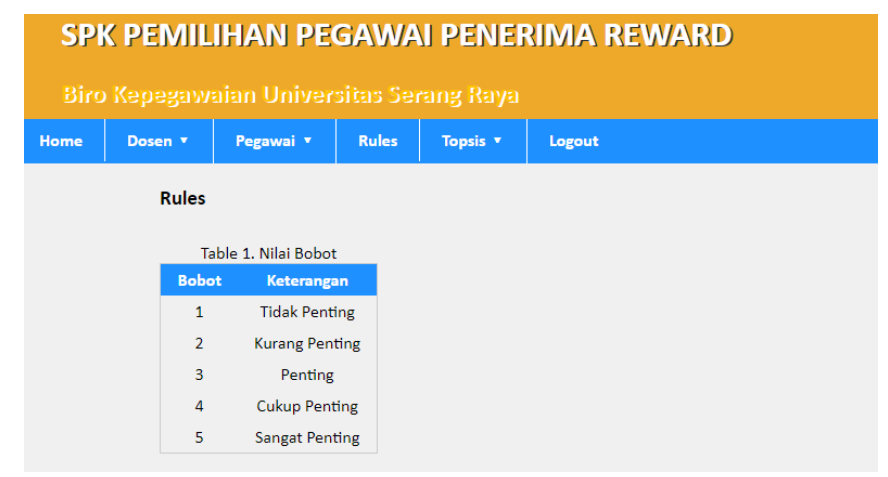

\section{Gambar 9. Tabel Nilai Bobot}

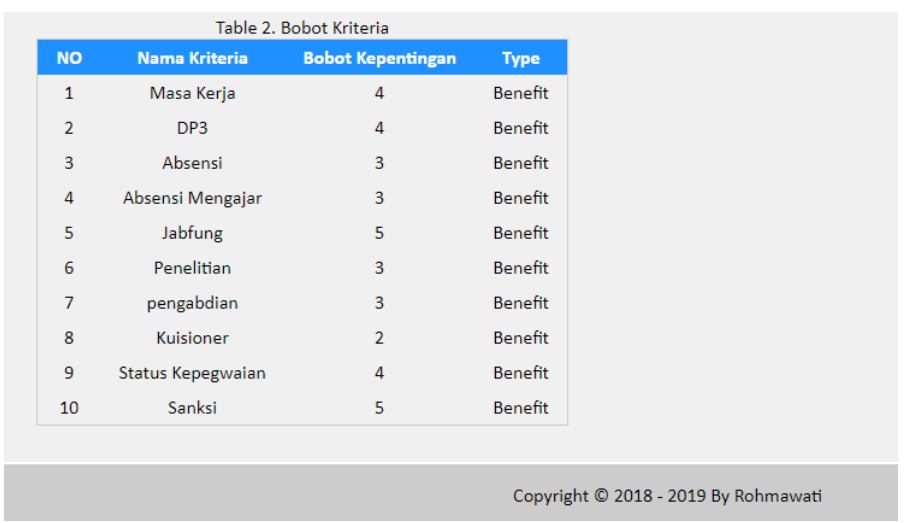

Gambar 10. Tabel Nilai Bobot Kriteria

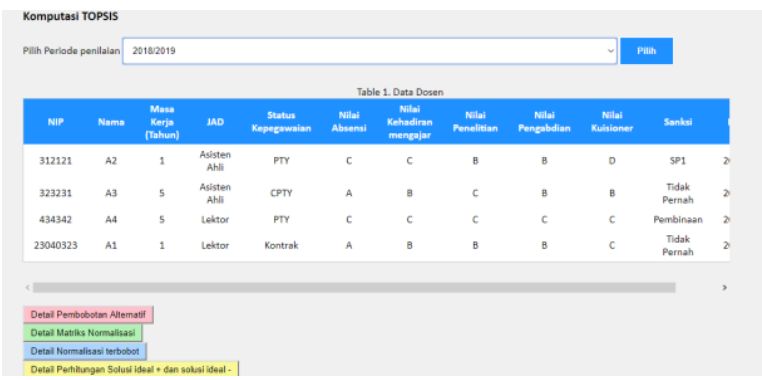

Gambar 11. Komputasi TOPSIS Dosen (Data Dosen)

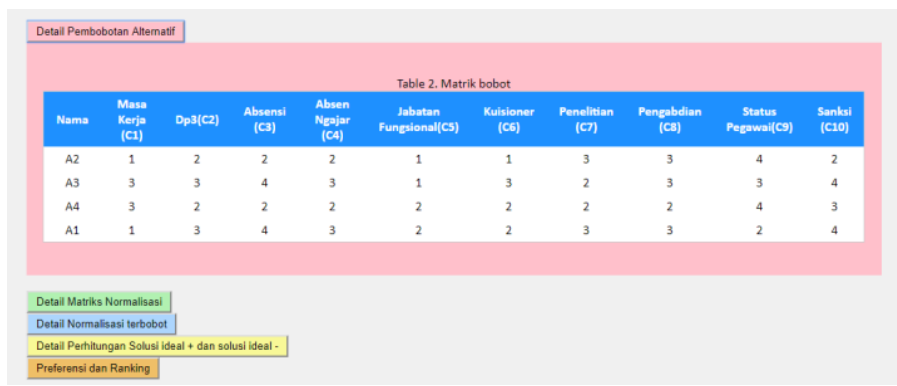

Gambar 12. Komputasi TOPSIS Dosen (Pembobotan Alternatif) 


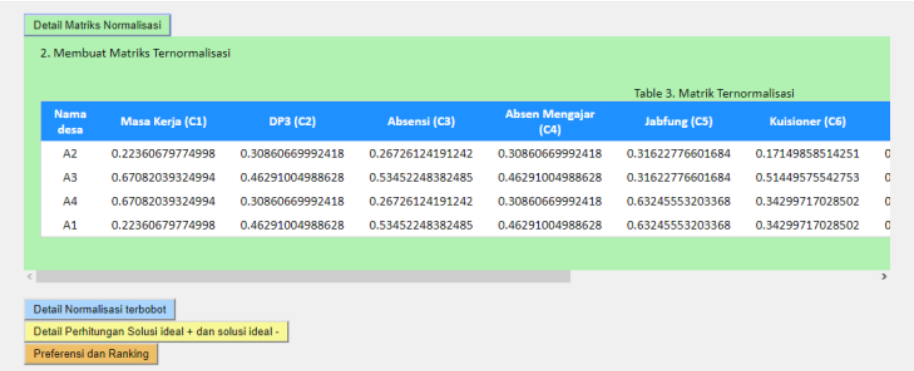

Gambar 13. Komputasi TOPSIS Dosen (Matrik Normalisasi)

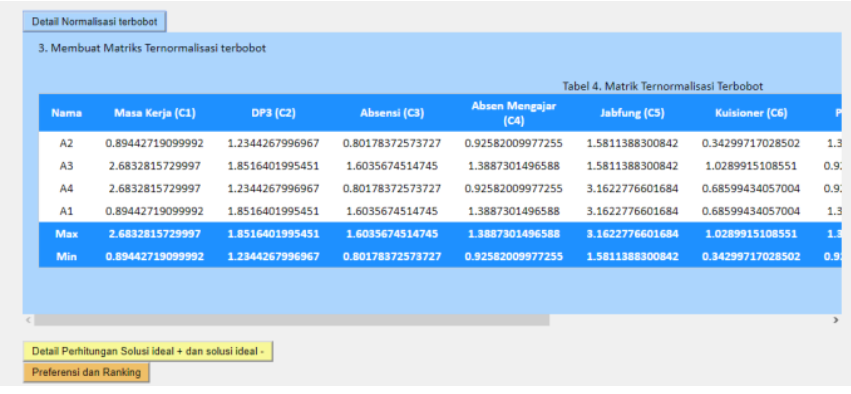

Gambar 14. Komputasi TOPSIS Dosen (Normalisasi Terbobot)

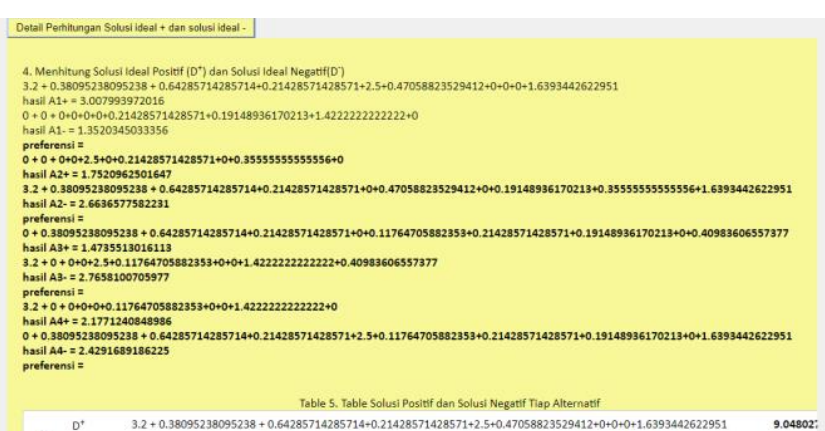

Gambar 15. Komputasi TOPSIS Dosen (Perhitungan Solusi Ideal + dan solusi ideal -)

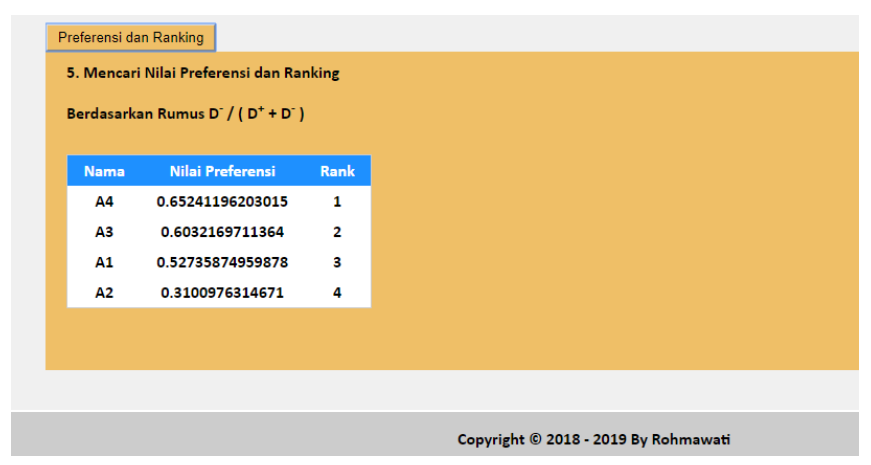

Gambar 16. Komputasi TOPSIS Dosen (Preferensi dan Ranking) 


\section{KESIMPULAN DAN SARAN}

\section{Kesimpulan}

1. Dalam perhitungan penentuan pegawai penerima reward di Universitas Serang Raya menggunakan kriteria yang digunakan dalam penentuan tercapainya objektivitas hasil keputusan sistem pemilihan pegawai dengan kriteria yang digunakan dalam penentuan pegawai penerima reward terdiri dari dua klasifikasi yaitu : dosen berdasarkan kriteria : masa kerja, nilai Daftar Penilaian Pelaksanaan Pekerjaan (DP3), nilai prosentase kehadiran, nilai prosentase kehadiran mengajar, jabatan fungsional, nilai penelitian, nilai pengabdian, nilai kuesioner, status kepegawaian, SP/sanksi dan pegawai berdasarkan kriteria : masa kerja, nilai Daftar Penilaian Pelaksanaan Pekerjaan (DP3), nilai prosentase kehadiran, status kepegawaian, SP/sanksi untuk mendapatkan reward di Universitas Serang Raya

2. Dengan digunakannya sistem pendukung keputusan sebagai alat dalam penentuan pegawai penerima reward dapat memberikan alternative terbaik di Universitas Serang Raya dengan menggunakan metode TOPSIS (Technique for Order Performance by Similarity to Ideal Solution) maka akan tercapai objektivitas hasil keputusan sistem pemilihan pegawai dibandingkan dengan sistem manual serta dapat menyajikan laporan yang dibutuhkan.

3. Digunakannya sistem pendukung keputusan sebagai alat untuk memilih pegawai penerima reward sehingga Rektor dapat melakukan pengambilan keputusan berdasarkan rekomendasi sistem yang dibuat.

\section{Saran}

1. Penggunaan Metode TOPSIS (Technique for Order Performance by Similarity to Ideal Solution) dapat diterapkan bukan hanya untuk menentukan pegawai penerima reward saja tetapi dapat diterapkan untuk pemecahan masalah lainnya.

2. Kriteria dan Bobot yang digunakan dalam menentukan pegawai penerima reward dapat dikembangkan untuk penyempurnaan pengembangan sistem.

3. Penggunaan metode Sistem Pendukung Keputusan dapat menggunakan metode lainnya sehingga dapat dijadikan perbandingan nilai dan rangking yang dihasilkan untuk pengembangan sistem. 


\section{REFERENSI}

A. Muri Yusuf, M.Pd. 2014. Metode Penelitian Kuantitatif, Kualitatif dan Penelitian Gabungan. Edisi Pertama. Jakarta. Kencana

Arbelia, Paryanta, Penerapan Metode AHP dan TOPSIS Sebagai Sistem Pendukung Keputusan Dalam Menentukan Kenaikan Jabatan Bagi Karyawan, Jurnal Ilmiah Go Infotech, Vol 20 No. 1, Juni 2014

Bunga Anneta Benning, Indah Fitri Astuti, Dyna Marisa Khairina, Sistem Pendukung Keputusan Pembelian Perangkat Komputer dengan Metode TOPSIS Studi Kasus CV. Triad, Jurnal Informatika Mulawarman, Vol. 10 No. 2, September 2015

Amelia Nur Fitriana, Harlina, Handaru, Sistem Pendukung Keputusan Untuk Menentukan Prestasi Akademik Siswa dengan Metode TOPSIS, Citec Journal, Vol. 2 No.2, Februari -April 2015

Abdul Rasyid, Septya Maharani, Implementasi Technique For Order Preferences By Similarity To Ideal Solution (TOPSIS) Pada Seleksi Asisten Laboratorium (Studi Kasus : Laboratorium RPL FMIPA Universitas Mulawarman), Jurnal Informatika Mulawarman, Vol. 11 No. 2, September 2016

Agus Irawan, Rochmawati, Decision Support System for Alternative Site Selection of Kkn using TOPSIS, International Journal of Computer Applications (0975 8887) Volume 150 - No. 7, September 2016

Agus Perdana Windarto, Implementasi Metode TOPSIS dan SAW dalam memberikan Reward Pelanggan, Kumpulan Jurnal Komputer (KLIK) Vol. 04 No. 01 Februari 2017

Ahmad Abdul Chamid, Penerapan Metode TOPSIS Untuk Menentukan Prioritas Kondisi Rumah, Jurnal SIMETRIS, Vol 7 No. 2. November 2016

Aysel Gundogdu, PhD, Measurement of Financial Performance Using TOPSIS Method for Foreign Banks of Established in Turkey between 2003-2013 Years, International Journal of Business and Social Science, Vol. 6 No. 1, Januari 2015

Diana Fatmawati, Sultoni, Sadikin, Sistem Pengambilan Keputusan Kelayakan Bagi Calon Penerimaan Dana Bantuan Masyarakat Miskin Menggunakan Metode TOPSIS Berbasis Web, Jurnal Informatika Merdeka Pasuruan (JIMP) Vol. 1 No. 1. Maret 2016

Erratul Shela Eshak, Nur Faithzah Jamian, Minirah Mohd Jidi \& Norlinda Zakirai@Zakaria, The Relationship Between Reward System With Employees' Performance, e-Proceeding of the Social Sciences Research (ICSSR 2016) 
Efraim Turban, Jay E. Aronson, Ting-Peng Liang. 2005. Decision Support Systems and Intelligent Systems (Sistem Pendukung Keputusan dan Sistem Cerdas). Edisi 7 Jilid 1. Yogyakarta. Penerbit Andi

Fred Luthans. 2006. Perilaku Organisasi. Edisi 10. Yogyakarta. Penerbit Andi

I Made Arya Budhi Saputra, Retantyo Wardoyo, Sistem Penunjang Keputusan Kelompok Penentuan Karyawan Terbaik Menggunakan Metode TOPSIS dan Borda, IJCCS Vol. 11 No. 2 Juli 2017, pp 165-176

Isaack, Dinah Kipkebut, The Effect of Reward Management on Employees Commitment in The Universities in Nakuru County-Kenya, Journal of Human Resource Management, 2016. Vol. 4 Nomor 4. 37-48 http://www.sciencepublishinggroup.com/jhrm

Kamaluddeen Magaji Doka, Fadhilah Ahmad, Syadiah Nor Wan Shamsuddin, Wan Suryani Wan Awang and Norliza Ghazali, Integrated Decision Support System for Human Resource Selection Using TOPSIS Based Models, Applied Mathematical Sciences, Vol. 9, 2015, no. 129, 6403 - 6414 HIKARI Ltd, www.m-hikari.com http://dx.doi.org/10.12988/1ms.2015.53288

Kwangjai Won, Eun-Sung Chung and Sung-Uk Choi, Parametric Assessment of Water Use Vulnerability Variations Using SWAT and Fuzzy TOPSIS Coupled with Entropy, Sustainability 2015, 7, 12052-12070;doi:10.3390/su70912052 www.mdpi.com/journal/sustainability

Marsono, Ahmad Fiti Boy, Wulan Dari, Sistem Pendukung Keputusan Pemilihan Menu Makanan pada Penderita Obesitas dengan menggunakan Metode TOPSIS, Jurnal Ilmiah SAINTIKOM sains dan komputer, Vo. 14 No. 3, September 2015

Prabowo Pudjo Widodo, Herlawati. 2011. Menggunakan UML Unified Modeling Language. Cetakan pertama. Bandung. Penerbit Informatika

Rajesri Govindaraju, Muhammad I. Akbar, Leksananto Gondodiwiryo, Tota Simatupang. The Application of a Decision-making Approach based on Fuzzy ANP and TOPSIS for Selecting a Strategic Supplier. Journal of Engineering and Technological Sciences. vol 47 no 4,. 2015. 406-425

Rashmi Ranjan, Dr. Umesh Mishra, Impact of Reward on Employee Performance:A Case of Indian Oil Corporation, Patna Region, IOSR Journal of Business and Management (IOSR-JMB) Vol. 19. Issue 6. Ver. II (June 2017). PP 22-30

Rizky Ratna Panggali, Fitri Marisa, Dwi Purnomo, Sistem Pendukung Keputusan Untuk Menentukan Judul Skripsi Jurusan Teknik Informatika Menggunakan Metode TOPSIS, Jurnal Informatika Merdeka Pasuruan (JIMP) Vol. 2 No. 1. Maret 2017 
Rohmatulloh, Sri Winarni. TOPSIS Method for Determining The Priority of Strategic Training Program. International Journal on Advanced Science Engineering Information Technology. Vol 4 No 2. 2014

Rosa A.S, M. Shalahuddin. 2016. Rekayasa Perangkat Lunak Terstruktur dan Berorientasi Objek. Cetakan keempat. Bandung. Penerbit Informatika

Sudaryono. 2015, Metodologi Riset di Bidang TI (Panduan Praktis, Teori dan Contoh Kasus). Yogyakarta. Penerbit Andi

Susan E. Jackson, Randall S. Schuler, Steve Werner. 2011. Pengelolaan Sumber Daya Manusia Managing Human Resources. Buku 2 Edisi 10. Jakarta. Penerbit Salemba Empat

T. Miranda Lakshmi, V. Prasanna Venkatesan, A. Martin, Identification of a Better Laptop with Conflicting Criteria Using TOPSIS, I.J. Information Engineering and Electronic Business, 2015,6,28-36 Published Online November 2015 in MECS (http://www.mecs-press.org/) DOI: 10.5815/ijieeb.2015.06.05

Tim Dosen. 2016. Rekayasa Perangkat Lunak. Pusat Bahan Ajar dan eLearning. Universitas Mercu Buana.

Vickky Listyaningsih, Ema Utami. Decision Support System Performance-Based Evaluation of Village Government using AHP and TOPSIS Methods: Secang Sub-district of Magelang Regency as a Case Study. International Journal of Intelligent System and Applications. 2018

Wang Yinghui and Li Wenlu, The Application of Intuitionistic Fuzzy Set TOPSIS Method in Employee Performance Appraisal, International Journal of u-and eService, Science and Technology, Vol. 8. No. 3 (2015), pp 329-344

Yani Sugiyarti. 2011. Metode Penelitian di bidang komputer dan teknologi informasi. Cetakan pertama. Banten. Dinas Pendidikan Provinsi Banten 